\title{
FROM BOTANICAL BIOGRAPHY TOWARDS ANIMAL ICONOLOGY
}

\author{
FRANS VERDOORN 1 ) \\ (Biohistorical Institute of the University of Utrecht)
}

(received December 10th, 1965)

This essay is mainly a restatement of the biohistorical ideology such as we developed it during recent years. At a recent international congress, I tried to present this in a detached, logical way (1965). At other times, I endeavoured to clarify it by using a case history (1964). In both cases, certain things remained unexplained and I will now try to elucidate the development of our biohistorical ideology along somewhat different lines. In doing so I shall avoid unnecessary personal reminiscences, but some facts of a personal nature or relating to the development of our Institute necessarily will have to be recapitulated in this connection. Many factors are involved, ranging from the increase in our staff, to the augmenting interests of our students (which forces us to pay some special attention to their education and, just as any editor will learn much through his editorial activities, one learns so much more by teaching than I formerly understood or expected). Other factors again are the increase of our library holdings and documentation programme, talks with colleagues (particularly in the literary faculty) and those visitors from abroad who do not come only - welcome as they are - to copy certain data from various sections of our Index Ultrajectinus (a world index of the literature of biohistory, entirely separate from our Library Catalogue).

Then, one makes schemes which frequently do not materialize rightaway, but which nevertheless are most helpful in planning for the future. As to our ideology, there is very little new in it, if considered from the point of view of the great medical humanists of the past. The materia medica, however, is only partially identical with the materia biologica and it took me many years to apply the ideology of the medical humanists to our own subject matter. Most medical historians always considered it a very natural thing to enter a variety of humanistic pastures and, whenever their rambles went beyond the traditional fields of history s.s., they never felt an urge to employ another term for whatever they were doing than "history of medicine".

I just wrote about a restatement of our biohistorical ideology - before there was any reshaping to be done, we underwent a formative period and I must acknowledge, in this connection, what we learned from many medical historians in New England (particularly the medical members of the Boston Biohistorical Club) and others

\section{1) Communicationes Biohistoricae Ultrajectinae 5.}


in centres at Yale, Manhattan, Baltimore's Johns Hopkins, and Washington, D. C. Why was it that in reshaping a club, which since the days of Harvey Cushing had never felt the need to call itself otherwise than the "Boston Medical History Club", the need was felt to employ the term "Biohistory" (a term of which we knew that it had been employed in the past occasionally in various other senses, such as phylogeny, etc.)? As it came to happen, a group of workers in the life sciences with humanistic interests - where man is both a subject and an object - joined forces with an existing nucleus of men of medicine. To the average biologist "history" means "history s.s.", and if he tries to extend his historical interest, he mostly enters theoretical biology or some related field of the philosophy of biology. As our interests were different, we felt the need for another term which since has been utilized by several others, in the U.S.A. and Europe.

In these and following considerations, I will avoid the mention of personal names in order not to sun myself in the fame of many men of renown, but an exception should be made for the late George Sarton to whose kindness my wife and $I$ owe so much, to the late Dr. E. D. Merrill who, whenever he wished, was not only a great taxonomist, but also an astute citizen in the republic of letters (1946 \& 1954), to the late Dr. H. E. Sigerist and, particularly also, to two men I never knew personally, Charles S. Sargent, the founder of the Arnold Arboretum, and to the Swiss zoologist, the late Prof. R. Burckhardt.

It was in the early 1940's, shortly after settling in the U.S.A., that I found the Arnold Arboretum Library at Jamaica Plain, Mass., a wonderful place to gather further data for a project started before the Second World War, the Index Botanicorum, a biographical dictionary of plant scientists of all types and all periods (VERDoorN, 1937 \& 1944). With the aid of the resources of the Arnold Arboretum, an interleaved copy of the second edition of Pritzel's Thesaurus Literaturae Botanicae, with which my wife and I had started gathering biographical data, was soon extended to a fairly extensive card index by combing journal after journal, and book after book.

In doing this, I received much help from various staff members of the Arnold Arboretum, such as Capt. V. G. Asmous, Dr. L. Croizat, Mrs. J. Sellars, Dr. A. Rehder, Dr. A. C. Smith, and, later particularly also, from Mrs. Lazella Schwarten. At one time, in the mid-1940's, in addition to my wife and Mr. K. W. Baron, five typists were busily copying and compiling-in not too large a house at Waltham, Mass. - what is now the Index Biographicus of the Index Ultrajectinus of the Utrecht Biohistorical Institute.

Many of those who worked at the Arnold Arboretum, its Herbarium and Library, were primarily or exclusively concerned with taxonomy and not always realized that they were working in an institution built up by a man, the late Charles Sprague Sargent, who was - to phrase it as briefly as possible - if not a botanical, at least a "dendrological Osler". For many years, I too, was not too much aware of this, for my approach to the history of the plant sciences and related subjects was very much along biographical lines. A feeling that man as the maker of the science of plants is an extremely 
important factor in the history of the plant sciences was forcefully instilled in many of his students by the late Prof. F. A. F. G. Went who taught his pupils, time after time, illustrating his views with a variety of examples, frequently derived from current work in experimental stations in the former Netherlands East Indies, that plants alone do not yield a grain of botany, but that man, the maker of botany, is a factor without which botany would not exist and also, that it is utterly foolish to make a sharp distinction between the pure and applied plant sciences (VERDOORN, 1938). This, of course, applies to many fields of science and learning and is hardly a very original idea which will seem very childish expressed to colleagues in the Interfaculty. Yet, I never had an other teacher who returned, time after time, to this subject in his courses for graduate students and who, via the first series of Chronica Botanica (which was only concerned with man as a factor in current and projected plant science research), made me turn to botanical biography which is still very close to my heart and to which the largest division of our Institute is devoted.

To return to the Arnold Arboretum, in its rich and well organized library I gradually found much more - as one may well expect in the heritage of a "dendrological Osler" - than data for the Index Biographicus. On the one hand, my interest in botanical gardens and arboretums, both their history and ideology, somewhat latent since I had the opportunity to work in our Hortus Bogoriensis in 19302) was revived and for many years, the past, present and future of botanical gardens received much attention (VERDOORN, 1948 \& 1953). World indices were started as well as a collection of books etc. which one now finds in the Bio-Topographical Division of our Institute. With the idea of building up something like the Sargentian heritage, I acted as organizing director of the newly established Los Angeles State and County Arboretum during 1948/1949 (VERdoorn, 1948) which was a most interesting experience during which I made a "master plan" and also learned the difference between the American West of fiction and of fact. Whenever time permitted, a variety of data were gathered in the wonderful Huntington Library at San Marino.

At least as important where the "discoveries" subsequently made in a number of minor library sections built up by C. S. Sargent, ranging from travelogues to works on trees in creeds and religions, and from the influence of deforestation on world history to wood utilization through the ages. Though realizing that many of these subjects were interrelated or, at least, had some bearing on each other, it took me quite some years to coordinate all this ${ }^{3}$ ).

2) I should admit that my interest, at that time, was mainly in scraping hepatics from the barks of trees and observing the enormous influence of such factors as light and humidity on the variability of hepatics.

s) I recall how George Sarton, who had never visited the Arnold Arboretum Library before, said-ca. 1947, during a visit there by the members of the Tannery Club-something like "amazing.... so many humanistic aspects represented in a botanical institution". This was long before I was truly aware of the essential 
Books, card indices, and all kinds of other biohistorical documentation first filled one house in Waltham, Mass., then a second one. It was at this time, in the mid-1950's, that Prof. Lanjouw was instrumental in enabling me to set up a University institute at my Alma Mater. I am well aware that many American friends felt that this could have been accomplished by joining forces with one of their medico-historical institutions. Important as early medicine may be to us, I wanted, however, to set up a biological institution. Some Utrecht University authorities were, initially perhaps, mainly thinking in terms of teaching the traditional history of the organic sciences. This is being done, not only bij offering a course, etc. in biohistory, but also by making it possible that post-candidate students can work at our Institute during either 3, 6, 9, or 12 months towards their doctorate, an opportunity which exists in very few biological (sub) faculties throughout the world. Biohistory, however, offers those, who desire so, a variety of other exciting possibilities.

Several years before I was enabled to set up the Utrecht Biohistorical Institute, it dawned on me that the interrelationships between the life sciences (incl. certain aspects of chemistry, and a good amount of medicine) and the humanities were essentially different, or at least have an entirely different spectre, than we find in the exact sciences or in science considered as a whole. I wrote previously about this, but now feel that I did not make things too clear, either in an address prepared for the Florence Congress of the History of Science, etc. (VERDOORN, 1951 \& 1956) or my inaugural address at Utrecht (1958) as I was still thinking too much in terms of historiography, biography, bibliography. etc.

By teaching, by collecting, by abstracting, and above all, by the freedom allowed by the Netherlands academic tradition, it gradually became clear to me that my original definition of biohistory as "the history and related humanistic aspects of the life sciences" should be more properly replaced by "the historical relationships of plants, animals, and man in science, early medicine, and culture". According to this principle we now distinguish 7 primary branches of biohistory, for most of which we are developing a division, sc.:-

1) The Formative Periods. The history of the interrelationships between plants, animals, and man (from the Palaeolithicum through the Middle Ages) is extremely interesting as during most of these periods languages, creeds, literature, art, plants and animals in daily life, as well as medicine, were more closely interrelated than during later periods. The special aspects of the Hellenic period should be

differences between the humanities and science and the problems involved in the possibilities of bridging the two. The removing of the unique Sargentian Library from Jamaica Plain, Mass., to Cambridge, where it was incorporated with other collections and where its charming and stimulating open stock nature was lost -I am certain with the most honest intentions of those involved-nevertheless was felt as a cruel act by many. 
recognized, as well as the fact that no research of any of these periods can be undertaken unless the languages concerned ${ }^{4}$ ) have been properly mastered.

2) The Life Sciences, early Medicine, etc., during the Renaissance and later periods. I wrote previously (e.g., 1944, 1951 \& 1963) in detail about a variety of aspects of the history and historiography of the life sciences, particularly its methodology, biography, bibliography, the history of the applied plant sciences, garden history, etc., and will not summarize these views again (cf., however, some of the concluding remarks). I may only add that, as per our understanding with the Utrecht Institute for the Philosophy of Science, we will in general restrict our programme, as far as the philosophical aspects are involved, to (a) the interrelationships between the history of philosophy and the history of the life sciences, (b) the history of concepts in theoretical biology, etc., and (c) the philosophy and methodology of historiography.

3) The Ethnological Aspects (post-mediaeval \& comprehensive). We have quite some documentation on ethnobiology, folklore, etc., but are reluctant to enter into research in social anthropology, a field which greatly developed in recent decades (which, i.a., would call for adding a motif index to the Index Ultrajectinus). It should be recognized that which is called "ethnobotany", etc., in many institutions of systematic biology touches only on certain, though basic, aspects of this and I should like to quote briefly from ARMSTRONG's (1964) latest definition of folklore (with special reference to birds - in which the term folklore, however, is applied in an unusually broad sense):

"A branch of social anthropology dealing with data in which birds figure, including local names, proverbs, legends, myths, folktales, rituals, and symbols. Aspects of the human exploitation of birds, such as devices for trapping them and the use of their plumage as adornments or parts of their bodies as medicine, are also relevant. Hunting and fowling were the mainstay of life in Palaeolithic times, and traces of beliefs and rituals concerned with increasing the fertility and vulnerability of prehistoric man's quarry survive in extant traditions. Thus folklore is indispensable as one of the few sources of information concerning the modes of thought and spiritual life of earlier communities. The importance which preliterate peoples attached to birds as beings possessing supernatural powers is attested by cave art, wherein men are represented with bird-like heads-probably masks, and by the myths in which birds participate in creation or have vital cultural roles attributed to them".

4) Biocontrol (post-mediaeval \& comprehensive). We had to coin this term for the history of man's domination of nature, a variety of

4) For this reason, we concentrate to some extent on the PalaeolithicumNeolithicum (which will call for a biohistorical laboratory), on the Ancient Far East (many holdings, but no sinologist, as yet), and the Middle Ages (both as Utrecht University is a great centre for mediaevalistic studies and as this period is very important to our "Bio-Symbolon Workgroup"-we realize that some knowledge of Greek and Latin, a slight knowledge of Arabic and the ability to utilize various dictionaries of late Latin, and other mediaeval languages are utterly insufficient, but this period is biohistorically of such a tremendous interest that a staff able to cope with it just will have to be built up). 
subjects, frequently and confusingly interpolated in dealing with the history of the life sciences. It includes such subjects as the history of man-land relationships, certain aspects of the history of domesticated plants and animals, the history of hunting and fisheries, nutritional history, "disease and civilization", the very extensive history of biotechnology, etc.

5) The Literary Aspects (mediaeval, later \& comprehensive). Our medical colleagues have always been much interested in these, and oak-paneled rooms filled with novels and poetry, by and about physicians, as well as didactic poems, etc., will be found in many of the large medico-historical institutions. The same type of literature exists about plants and animals, and to a much minor degree than in medicine, biologists have entered the domain of the "belles lettres". This, however, is only one aspect. At least as important from our point of view is the literature in which animals (and to a minor extent plants) play a symbolic role. The prototypes of this type of literature, incl. much mythological, sacred and devotional literature, frequently date back to the formative periods. These myths, early religious concepts, bestiarii, fables, emblemata texts, etc., are a most typical example of what is considered of the utmost importance in one faculty and may seem utterly foolish to many in a faculty concerned with stellar physics and molecular biology. It should also be recalled that this type of literature is not only of importance for its own sake, but also both to those concerned with the ethnological and particularly with the art historical aspects.

6) Art Historical Aspects (mediaeval, later, \& comprehensive). Many biotaxonomists claim to be interested in these, but in general they refer to the graphic arts (as exemplified, let us say, by Gould or Redouté), to typographical history, etc. It is true, Gould and Redouté were great artists, but their importance is mainly iconographical (s.s.) and not iconological, i.e., without a spiritual meaning. I hardly need to say that the graphic arts, in their multivarious aspects, greatly concern and interest us. Some of the most interesting problems in biohistory, however, are concerned with the symbolism of plants, and animals, as well as with pharmaceutical and medical representations in mediaeval, Renaissance and Baroque art. Long ago, I used to spend many a Saturday afternoon gathering data mainly relating to plants and horticulture, along these lines, in Harvard's Fogg Art Museum. Then, I turned to those few icones of certain emblemata in which plants are.of some real importance, etc. Gradually, however, it became clear that animals as symbols, attributes, allegories, etc., have been a tremendously more important aspect of civilization, through the ages, and that much of it is still obscure. One needs a knowledge not only of systematic zoology, but occasionally also of such unexpected fields as endocrinology, etc., in addition to a thorough knowledge of the literary sources, sacred and profane, a perfect understanding of the many facets of symbolism (the unspoken language of the ages, from the mesolithic rock paint- 
ings to the folk prints of scarcely a century ago), and above all of "l'imagerie de l'art chrétien médiéval".

7) The Linguistic Aspects offer the properly trained biohistorian intriguing problems with which, at present, we just cannot cope in spite of the fact that we gathered a good collection of "natural history" and related dictionaries of all types (arranged chronologically until 1900 , and alphabetically by authors after 1900). We also gathered a good number of etymological studies, but ever since I went through such works as Gottfried's Pelzbuch by Eis or Die Deutsche Vogelnamen by Suolathi, I have felt that this subject matter can best be tackled by biohistorians in cooperation with properly trained linguists, in which the latter should have the last word ${ }^{5}$ ). Of particular interest also is the very early history of writing in which plants and animals are frequently represented, both to identify them as well as symbols.

According to its title, this essay should now come to an end; yet, I may be permitted a few final remarks.

In history, particularly in biography, the formative and causative factors are often overlooked with the result that by neglecting the matrical factors ${ }^{6}$ ) a very one-sided and non-analytic picture is frequently given. To the historiographer of early botany, it may not mean much that, e.g., Ernst Meyer, throughout his life was deeply influenced both by Albertus Magnus and Goethe, yet, his classic Geschichte cannot be properly appreciated unless one is well aware of this. This is just one example; giving proper attention to the matrical factors, whatever the subject, is not only essential in, but the essence of biohistorical work.

To return once again to bio-symbolism, the Physiologus is hardly a classic ot animal science (though it yields some unexpected data). Biohistorically it is a mos interesting example of the fact that one has to be familiar both with literary history of a great variety of types (incl. the canons of the great religions), with art history (particularly iconology), and, last not least, with certain aspects of social anthropology, each of which may derive again profit from work in a related field. To which extent such "scientific oddities", in a related field, played an enormous role in cultural history has recently been analyzed by Dr. H. M. E. DE JoNG (1965).

In the meantime various subjects, such as biography, bibliography, historical biotopography, which I considered at one time as "prime branches" of biohistory, now appear only methods or aspects of historiography, etc. It should, however, be emphasized that they often call for very extensive reference divisions operating according to the special methods involved in which connection our Biographical Division, in the long range, will continue to have priority.

Then, considering our Institute and our developmental plan, we have or need certain divisions serving our Institute as a whole (the Index Ultrajectinus, with minor exceptions, e.g., can be maintained only

5) The dangers of "wisdom without understanding" resulting from a one-sided approach have been outlined, in this connection, often rather caustically, by the late Dr. E. D. Merrill (e.g., 1946 \& 1954).

6) An other term for which I felt a distinct need. 
centrally). On the other hand, there is a need for certain special work or study groups (such as our Bio-Symbolon Workgroup and our "Dutch Golden Age Study Group", i.e., the Leeuwenhoek Commission, etc.). I also did much preparatory work towards a study group for the history and technique of international relations in the life sciences in a detached and academic way, etc. Some of these work or study groups may operate entirely within the framework of the Biohistorical Institute, but mostly they will call for interfacultary, national or international cooperation.

Then, a biohistorical serial must be started as soon as proper care will have been taken of certain arrears and, sometime in the 1970's, an international advanced course in biohistory should be added to our educational programme.

"History, etc., should not be a goal by itself, but a tool for the present" claim some historians (occasionally quoting such dicta as Fr. Bacon's "itaque ipsissimae res sunt ... veritas et utilitas"). This will often hold true, but as a categoric statement, it sounds rather Hitlerian. As to biohistory, some projects will be purely academic, whereas others may be of a tremendous help to a variety of workers in non-historical fields. A properly balanced biohistorical institute, at the same time, can be a most useful documentation centre for sundry workers in the life sciences (to which we are giving much thought and attention in connection with the transfer of our Institute - sooner or later - to the "Uithof", the new campus of our University in a suburban area near de Bilt). Yet, whatever the use of pinpointing publication dates, biographical dictionaries, special subject bibliographies, etc., may be, it seems more important, as Sigerist often pointed out, that history, etc., can permit us to bring certain humanities close to the scientists and to teach a scientific outlook to the students of certain humanities in a language that both can understand, broadening their horizon and preventing them from becoming narrow specialists?). Ceterim, what is the "use" of music, what is the "use" of art ...?

In concluding I must point out that it cannot be helped that some projects, for which my wife and I previously gathered much material, have occasionally, to some extent, temporarily been replaced by other projects (for which less material was gathered). It should also be understood that I gradually revised our programme, both according to the resources of Utrecht University (scant in some ways, on the niveau of the best universities of the world in other cases) and the abilities of our devoted staff (now consisting of some eight members, most of whom were chosen on account of their potentialities besides their immediate abilities), as well as the hon. research fellows of the Int. Biohistorical Bureau, in the hands of all of whom rests the future of what we started and who join in paying tribute, at this occasion, to the initiative taken by Prof. Lanjouw.

7) This sounds as nice as it is difficult (particularly in continental universities which are mostly of the "graduate school type"; in general, resulting in unavoidable compartimenta). 


\section{REFERENCES}

Armstrong, E. A. 1964. Folklore. A New Dictionary of Birds, edited by A. L. Thomson, p. 317-319 (cf. also ARmstrong's "The Folklore of Birds". London, 1958).

Jong, H. M. E. DE. 1965. Michael Maier's Atalanta Fugiens. Diss. Utrecht.

MerriLl, E. D. 1946. Merrilleana: Selected Writings. Chron. Bot. 10: 127-394. 1954. The Botany of Cook's Voyages. Chron. Bot. 14: 161-384.

Verdoorn, F. 1937. The Index Botanicorum. Chron. Bot. 3: 335-336.

1938. Zuiver en Tcegepast ... Vakbl. Biol. 19: 224-235.

1944. Aims and Methods of Biological History and Biography. Chron. Bot. 8: 425-448.

1948. The Modern Arboretum: a center of regional, botanical and horticultural synthesis. Waltham, Mass. (Dutch version: Vakbl. Biol. 29: $121-127)$.

1951. From Empirism to Applied Science... Remarks on the need for institutions for certain branches of the history of science. Amer. J. Pharmac. Educ. 15: 338-348.

1951. Problems of Botanical Historiography. Arch. Int. Hist. Sci. 15: 448-457. (Dutch version: Vakbl. Biol. 31: 201-209).

1953. Botanic Gardens of the Past. Année Biol. 29: 275-282.

1956. Biohistory, its Aims and Scope. Coll. Trav. Acad. Int. Hist. Sci. 9: $762-769$.

1958. Iter Biohistoricum. 's-Gravenhage.

1963. Beknopt Overzicht van Hetgeen Bijgedragen is tot de Biohistorie. Vijftig Jaren Beoefening van de Geschiedenis der Geneeskunde, etc., in Nederland, p. 42-68.

1964. Biohistorische "Tree Test". Notulae Biohistoricae Ultrajectinae 8 (a similar biohistorical Bird Test, "The Ornis in the History of the Arts, Sciences, and Civilization" will be issued shortly).

1965. The Horizontal versus the Vertical Approach in the History of the Life Sciences. Procds. 11th Int. Congr. Hist. Sci. (to be published in Poland in Organon). 